\title{
Main Worldwide Cultural Obstacles on Adopting International Financial Reporting Standards (IFRS)
}

\author{
Abulkasem Dowa $^{1}$, Abdulmonem M. Elgammi ${ }^{1}$, Abdesalam Elhatab ${ }^{1}$ \& Hassan A. Mutat ${ }^{1}$ \\ ${ }^{1}$ School of Economics, Zawia University, Zawia City, Libya \\ Correspondence: Abulkasem Dowa, School of Economics, Zawia University, Zawia City, P.O. Box: 16418, Libya. \\ Tel: 218-92-525-4917. E-mail: s_dowa@yahoo.com
}

Received: December 14, 2016

doi:10.5539/ijef.v9n2p172
Accepted: January 1, $2017 \quad$ Online Published: January 10, 2017

URL: http://dx.doi.org/10.5539/ijef.v9n2p172

\begin{abstract}
In recent times, the history of a country's culture has become increasingly recognised as a crucial factor in its accounting methods. The globalization of the practice of economics has lead to homogenous international standards which are at the core of its development for practitioners, researchers and academics. This research considered some factors that might influence the adoption of International Financial Reporting Standards (IFRS) as cultural obstacles. This study investigates the religion, the language, technical skill and expertise as main cultural obstacles for the adoption of IFRS worldwide.

Findings revealed the incompatibility of many IFRS with principles of Islamic religion, and also many nonEnglish countries apply wrong implementation of IFRS because of translation issues of IFRS from English to their local languages. This study concluded that it is difficult to adopt IFRS in some countries and for some institutions because of the insufficient technical skill and experience of accountants and auditors to deal with those standards.
\end{abstract}

Keywords: culture, IFRS, religion, language, technical skill and expertise

\section{Introduction}

As a result of the rapid evolution of the global financial markets, it has become necessary to prepare financial statements for international comparison, and in order to investigate the full competition in this market (Irvine \& Lucas, 2006, p. 3). The movement towards conformity uniformity in international accounting results is resulting from the globalization of business and the need for a common set to conform to a universal set of accounting standards to facilitate investment and international trade (Fang, 2007, p. 121). These standards are called International Financial Reporting Standards (IFRS) which have been issued by the International Accounting Standards Board (IASB) in 2001 (Oluku \& Ojeka, 2011, p. 916). It is believed that eight factors in a country's environment have a significant influence on the differences found in accounting systems: main source of finance; taxation; legal systems; inflation; political and economic ties; economic development; and the culture (Shima \& Yang, 2012, p. 1). IFRS have been presented as high quality accounting standards that improve the value of accounting information across international borders (Ludolph, 2006, p. 17). Over 100 countries now require or allow IFRS for domestic reporting (Clements et al., 2010, p. 115).

\section{Research Design}

The purpose of this study was to address the main factors that would influence the adoption of International Financial Reporting Standards (IFRS) as cultural obstacles. In doing so, the study was based on an academic and theoretical literatures regarding the factors in a country's culture that believed to affect the process of adopting IFRS.

\subsection{Religion}

Religion is a cultural obstacle to the adoption of IFRS in some countries and some institutions. Its importance is the same across national boundaries and also has a vital influence on the way business is recorded and conducted (White, 2004, p. 6). According to Hamid et al. (1993, p. 134), "the incompatibility of many Western accounting practices with Islamic principles requires explanation." This comment shows that some of IFRS are incompatible with Islamic 'sharia' (law). This is incompatibility needs further research to explain. IFRS was released by Western countries through IASB in 2001 (Nandakumar et al., 2010). Islam does not determine only the religious 
practices such as prayer, but it determines even the commercial transactions which the Muslims must deal with in their lives (Azmi, 2010, p. 3). According to Lewis 2001 cited in (Alkhtani, 2012, p. 3), that based on the Sharia, Islam has a crucial role, in regulating business, and in how accounting should be undertaken finance and banking ought to be organized. For example, Islamic law prevents the payment of interest, but this is not taken into account in IFRS (Tyrrall cited in Alkhtani, 2012, p. 3). Also, Islamic economic and financial principles have a direct influence on accounting policies and practices. These principles, most importantly, contain the institution of 'Zakat', the prohibition of 'riba' (financial interest), and the institution of an interest-free economic system (Lewis, 2001, p. 106). (Note 1).

According to Lewis (2001, p. 117), there are three major differences between Sharia-based Islamic economics and those of the Western world. The first is complete prohibition of doing business with companies who deal with all things which are forbidden (haram) to Muslims for example gambling, alcohol, and pork derivatives. The second is the boycotting of 'Riba'. More acutely translated this means 'usury' and it is more generally used to mean 'interest'. The prohibition of riba comes from the Quran, which says: "Those who consume interest cannot stand [on the Day of Resurrection] except as one stands that is being beaten by Satan into insanity" (Quran, 2, p. 276). In Islam, it is not deemed acceptable for a money lender to have a pre-determined and assured return, whilst at the same time the borrower takes all risks; the same rules apply to preferred stock. The third difference is the deliberate efforts to refrain from 'gharar', which means 'speculation'. These three differences represent a path of obstruction to adopting Western accounting standards because charging interest is an essential part of most financing practices, such as the restructuring and the charging of fees for debt (White, 2004, p. 7). It is natural, that there are differences between the accounting principles and practices of the countries around the world. This is because of the difference in cultures religiously and linguistically and intellectually.

More specifically, the Islamic religion is at variance with certain International standards such as, disclosure standards (Harahap, 2002, p. 35). This means the conventional a balance sheet by Western standards does not conform to Islamic principles of accounting, particularly with regard to Zakat (charitable giving) (Wilson, 2004, p. 1). According to Ibrahim (2000, p. 34), Zakat is one of the main objectives of Islamic accounting. Therefore, there is a need for an accounting system capable of correctly calculating and revealing the amount of Zakat payable. Zakat is payable at a rate of $2.5 \%$ on any money which has remained untouched for one year as well as on salaries. 2.5\% is also the rate at which Zakat is added for trading enterprises, being calculated on net profit and net worth. On investment income a person must pay 10\% Zakat (Ibrahim, 2000, p. 35). Therefore, the conventional Western treatment of assets on a balance sheet is not appropriate for these calculations, and cannot provide the necessary information for the correct calculation of the amount of Zakat payable.

On the other hand, compliance with the Islamic tradition transcends national boundaries unlike the nationally driven cultural elements such as, the nationalism, and the language (Hamid et al., 1993, p. 134). This means that compliance with the Islamic principles is not only in Islamic countries while may be in countries which involve Islamic institutions. There are banks that follow Islamic banking in Western countries such as Westpac bank in Australia (La Trobe University, 2012). Also this evidence shows that religious factor is different from other cultural factors that do not exceed the national barriers of the state, language, customs and traditions.

Furthermore, although the incompatibility of many Western accounting practices with the principles of Islamic Sharia, "many Western accounting practices draw upon assumptions which conflict with the tenets of Islam" (Hamid et al., 1993, p. 134). Financial practices in Islam have an in-built system which is faithful to the individual's obligations to society and not to the rights of the individual (Esposito, 2002). The unity of God is the focus of an Islamic accounting system in contrast to the West where the essence of its system is on entity ownership (White, 2004, p. 7). In Islam, social accountability is a key to the whole community and is in opposition to a Western system which emphasizes narrowly focused personal accountability (White, 2004, p. 7). Under the Muslim code of law full disclosure in financial practices means making any accounting information available to members of the community (Baydoun \& Willett, 2000, p. 89). Therefore, the incompatibility of many Western accounting practices with the principles of Islamic Sharia has advantages and disadvantages on accounting world.

On the other hand, the accounting and auditing standards which are adopted by Islamic financial institutions (AAOIFI) are a reflection of the different financial instruments, insurance systems, contracts and interest laws, ethical standards, and the kinds of business organization that are used by them. These standards that differ slightly from those of the IASB are set by the AAOIFI which currently has 115 members from 27 countries (Anonymous, 2009, p. 1). Specifically, five specific issues separate the two with regard to leases, restricted contracts, and specialty investment accounts where the investors take part of the responsibility for the business risk (El-Razik, 2009, p. 4). Further, AAOIFI is not only supported by central banks and Islamic financial 
institutions in Islamic countries, but also by the international Islamic banking and finance industry around the world. Finally, religion is the element which most affects accounting practices especially the Islam because it determines how financial transactions should be done). (Note 2).

\subsection{Language}

Language is a cultural obstacle to the adoption of IFRS in some countries. Language is a cultural element that barely differs from many countries around the world. Of course, this difference affects the culture of human beings, especially, when they deal at an international using another language. The official working language of the IASB, and the language in which IFRS is published, is English. Then, some countries which need to translate IFRS to understand them before adoption sometimes face some obstacles to do that. This is because of the difficulty of translation of certain concepts. According to Tsakumis et al. (2009, p. 35), "[t]ranslation of IFRS into various languages poses another threat to accounting comparability". And also according to Evans (2004, p. 223 ) and Zeff (2007, p. 296), harmonization and standardisation of financial reporting will be severely hampered because of poor translation. This evidence indicates that the process of translating the international standards is not an easy process. This is because the process sometimes differs from person to person so they will get different results that hinder the comparison of financial statements that is the basis of the application of standards. In general, when any standard is translated wrongly or differently from the original meaning this will lead to misunderstanding that causes incorrect interpretation and implementation of IFRS. In essence, the professionals who prepare financial statements need to interpret and understand in a consistent manner the requirements included in financial reporting standards (session two- Background paper 2005, p. 4). Language is a huge issue in this regard. The IFRS are written in English and need to be translated into different languages (Christopher, 2011). It is possible that the some of the terms used could be lost in translation largely because there are no equivalent terms in the translated language (Zeff, 2007, p. 296). This would be an impediment to achieving comparable financial statements. In detail (Evans \& Baskerville, 2011, p. 37), identify specific issues relating to technical accounting concepts, the structure of sentences and grammar, or 'vague' expressions. They addressed five specific problem areas; uncertainty/ probability expressions; complexity of syntax/sentence structure or length of sentences; concepts with a broader or different meaning in 'everyday' usage; undefined or indefinable concepts and terms signifying different concepts or multiple meanings. According to Tsakumis et al. (2009, p. 37), "standards cannot be translated into other languages without some distortion of meaning." They point out some examples which refer to problems of translation. For example the word 'remote', which is used in IAS31 and IAS 37, can be translated into Spanish as 'vasto', 'remoto' or 'lejano' (online translation dictionary www.freedict.com) (Tsakumis et al., 2009, p. 38). However, 'remoto' can only be translated into English as 'remote'. Remoto also is used in the Italian and Portuguese translations of IFRS" (Tsakumis et al., 2009, p. 38). The translation of IFRS to any other language should be done by specialist commission in IASB to avoid duplication understanding of or understanding that resulting from a different translator.

In the context of the EU, it is essential that the financial language is linguistically clear and is understandable across all language platforms (Hellmann et al., 2010, p. 3). The original language of IFRS is English, but the endorsement process of the EU means that it has to translate IFRS into all official European languages (Hellmann et al., 2010, p. 3). This is an EU legal requirement and IFRS are not legally binding without their translation (Hellmann et al., 2010, p. 3). As such, if the translation of IFRS into various European languages is not well-organized and rigorously undertaken it poses a threat to comparability (Hellmann et al., 2010, p. 3). Doupnik and Richter (2003, p. 15) provide particular evidence about the differences that exist between English-speaking and German-speaking accountants for a large number of 'uncertainty' expressions. They argue that these differences in interpretation may be due to a culture effect or poor translation and clumsy mapping of certain expressions in the target language, respectively (Doupnik \& Richter, 2003, p. 15). According to Doupnik and Richter (2003, p. 19), there is some difficulty in translating certain English expressions into German. For example, the single word "remote" is translated into the three-word phrase "Wahrscheinlichkeit äußerst gering" (literal translation $=$ "probability extremely small" (Doupnik \& Richter, 2004, p. 2). This apparent lack of a direct equivalent expression in the two languages suggests that there may be a lack of equivalence in the underlying concepts.

However, There are positive relationships between countries where English is the main language and the adoption of IFRS. That is, although each of the English-speaking countries possesses a unique national culture, they might share a similar language-culture. The same is true for German-speaking countries, Spanish- speaking countries etc. Those countries who have a strong Anglo-American culture find the adoption of IFRS unproblematic (Chamisa, 2000). This means countries that are influenced by the Anglo-American tradition are most at home with putting their accounting standards into place and the most likely to be able to adopt them 
professionally (Chamisa, 2000, p. 277). In determining the direct influences on accounting we also see that a number of indirect effects are important to our understanding too. Sociocultural, political, educational and legal factors all influence accounting (Chamisa, 2000, p. 279). For example IFRS uses written symbols which have significance. Also features of clauses and paragraphs can depend on interpretation (Abd-Elsalam \& Weetman, 2003, p. 67). In other words, where IFRS is linguistically ambiguous some accounting in other countries may become inconsistent (Abd-Elsalam \& Weetman, 2003, p. 67). Generally, if the language and terminology used indeed affect the way we think, international harmonisation and/or standardisation of financial reporting will be severely hindered, as will be the appropriate application of rules in practice (Evans, 2004, p. 211). Then bad investment decisions can be made by a misunderstanding of foreign language financial statements

Consequently, concepts developed and embedded in the accounting in one country but which has never been used in a different country, may be misinterpreted, even if they have been applied as rigorously as possible (Zeff, 2007, p. 295). The sentences may be translated word for word but the concept may be estranged. Further, new IFRS concepts can be open to misunderstanding where there is no equivalent concept in the other country's history. This is especially true when the IFRS is addressing problems which have rarely occurred in the other country's experience.

\subsection{Technical Skills and Expertise}

Technical skill and expertise are cultural obstacles to the adoption of IFRS in some countries and some institutions. A significant challenge for the accounting profession is the availability of professionals with sufficient education and experience. (Sylwia \& Steve, 2010, p. 68). According to Sylwia and Steve (2010, p. 65), "audit professionals will need to demonstrate sufficient knowledge of IFRS in order to render an opinion on IFRS financial statements". Those who support auditors, such as information system consultants and taxation experts, need to demonstrate that their understanding of IFRS is good enough to provide audit support (Sylwia \& Steve, 2010, p. 65). "An example of this need is in the area of tax provision auditing" (Bohusova, 2011, p. 66). Tax professionals supporting IFRS audits will need to have a sufficient understanding of IAS 12, Income Taxes, in order to properly evaluate the tax provision (Bohusova, 2011, p. 66). In order to successfully apply IAS 12, it should develop a strong understanding of the main technical requirements of the complex standard, IAS 12. This understanding is through a practical approach to learn how to implement the tax calculations in accordance with this standard. Thus, presence of this approach depends first and foremost on the availability of qualified human and material potentials which are limited in some institutions and some countries.

IFRS is not appropriate for internal management of some institutions such as, small and medium sized companies (SMEs). This is because there is a lack of experts to do that (Aldu et al., 2010). According to Bohusova (2011, p. 210), "many small companies that lack accounting expertise would require to enlist professional help when adopting IFRS for small and medium sized companies (SMEs)". This evidence shows that it difficult to apply IFRS in SMEs. This is because the adoption of IFRS means that "accountants would have to redesign the internal processes, train staff on new accounting systems and produce restatements of comparative information" (Stokdyk, 2010) All of these processes are costly for SMEs because this kind of company has limited of funds and small capital (Mullerova \& Pasekova, 2010).

As well, the lack of skills and expertise that related with understanding and interpretation of IFRS is a cultural obstacle to adoption process in developing and poor countries. According to Shima and Yang (2012, p. 282) "countries with less sophisticated educational systems may find the transition to IFRS more costly to implement compared to other countries with better education systems". The more a population is educated the more sophisticated the country's accounting system has to be to meet its information requirements (Choi, 2008 cited Shima \& Yang, 2012, p. 282). The ability to apply and interpret ever more complex accounting practices and standards will depend on the level of education of the general population (Shima \& Yang, 2012, p. 282). Therefore, developed countries with a more highly educated population will be more likely to adopt IFRS and a problem of the adoption of IFRS wills inevitably remains in most developing countries.

On the other hand, issues related to education and professional development of adoption of IFRS in Middle Eastern countries (MEC) are important because area in developing .According to the Chairman of the IFRIC, Robert Garnett on (El Razik, 2009, p. 2) "with oil revenues being directed into large investments, the region is increasingly being seen as a potential partner". It will become increasingly important for IFRS to adapt to the wholly different environmental factors appreciated by the ISAB because Middle Eastern countries already play a role in global policies, investments and capital markets (El Razik, 2009, p. 2). It would be an advantage for MEC to follow IFRS instead of setting their own unification system for accounting and reporting. However, it is crucial that the concerns of its countries should be transmitted to the IASB (El Razik, 2009, p. 4). For global 
accounting harmonization to happen it is essential that a MEC representative should be invited to meet with the ISAB (Greggi, 2012, p. 37). It certainly would not cause harm and it would be an advantage to the problem of adaptation rather than IFRS establishing new regional sets (Greggi, 2012, p. 37). Unfortunately the current unavailability of highly qualified IFRS accounting and auditing staff in Middle Eastern countries is a huge barrier towards the adaptation and harmonization (Greggi, 2012, p. 37). The lack the expertise to deal with IFRS in these countries due to many reasons, such as, these countries is developing countries and, most of them are poor, therefore, it is inevitable these countries lack experts to deal with IFRS.

The lack of a sufficient experience of professional accountants in USA is one of the biggest challenges that facing the transition to the adoption of IFRS there. This is because of lack of accounting judgment of accountants in USA (Sylwia \& Steve, 2010, p. 66). Owing to the principles-based nature of the IFRS standards accounting professionals will be facing an ever-increasing use of expertise. This is in opposition to the generally rules-based standards of USA GAAP (Sylwia \& Steve, 2010, p. 66). According to the survey done on 2008 by Deloitte about need of US companies to adopt IFRS, there is a need for more IFRS-focused preparation and training. Regardless of interest in adopting IFRS, more than $60 \%$ say they lack an adequate number of personnel in U.S. operations that collectively have a level of IFRS knowledge to address a conversion to IFRS (Hail et al., 2009). In reporting using IFRS in the US it is a concern, even where a registrant has suitable expertise in IFRS it may not be the case their auditors have an equivalent technical skill to audit the company. This is especially true where large numbers of clients are reporting to IFRS on using the standards (Gupta et al., 2007, p. 30). This will cause particular concern when private companies that propose to issue an initial public offering on or after the established adoption dates must offer IFRS three years of financial statements (Doupnik \& Richter, 2003, p. 17). Therefore, those undertaking the education of accounting professionals should consider beginning with sophomore-level students by 2012. This will ensure that the finance and accounting professionals hired by companies will have the necessary skills to prepare and break down IFRS-instituted financial statements (Anonymous, 2009, p. 1).

Also, according to the survey is done about the challenges to adopt IFRS in USA by Big Four firm KPMG and the American Accounting Association, 83\% believe that IFRS needs to be incorporated into US curricula (Anonymous, 2009, p. 1). Therefore, this evidence also shows that education is a biggest challenge to transfer to IFRS in USA. According to PoriaI $(2009$, p. 3$)$ in India the lack of training facilities and academic courses on IFRS is the biggest obstacle for the professionals accountants in implementing IFRS. As Porial mentioned the implementation date draws closer (2011), it is observed that there is acute shortage of trained IFRS staff. "The solution to this problem is that all stakeholders in the organization should be trained and IFRS should be introduced as a full time subject in the universities" (Porial, 2009, p. 3). Finally, training and education of accountants will remain the best solution to deal with IFRS. But the cost and time for this facilitation will remain the biggest obstacle to the adoption of IFRS.

Insufficient technical skill and expertise of the implementation of IFRS are visible cultural obstacles in many countries around the world as mentioned above, in both, the developing countries, as well as in the developed countries such as the United States and also in other countries such as, Canada, and China. In October 2011, the Association of Canadian School of Business (AcSB) issued a preliminary report on the IFRS Transition Progress Review (The finance group, 2008, p. 1). The preliminary report highlighted many challenges with respect to Canada and preparation for the changeover, including: "uncertainty regarding the availability of training and skilled resources, and challenges with training and education" (The finance group, 2008, p. 1). Furthermore, according to study that is done in China by Ding and Su (2008, p. 474), the large number of accountants in many Chinese companies did not received sufficient training in modern accounting and auditing that relevant with implementation of IFRS. "An example of this need is in the area of tax provision auditing. Tax professionals supporting IFRS auditors will need to have a sufficient understanding of IAS 12, Income Taxes, in order to properly evaluate the tax provision" (Tomaszewski \& Showerman, 2010, p. 66).

\section{Discussion}

It would be hard to deny that the development of a harmonized set of excellent quality global accounting standards would not be beneficial internationally. These standards, recognized by all capital markets and their regulators, would be more than adequate for cross-border rising of capital (Baskerville \& Evans, 2011, p. 1). However, if this were to become a reality, it may not be enough to assure an equivalent quality in global reporting. The principal reason for this is that domestic cultural, political and legal impacts of the environments in that companies operate have a significant influence on the ways in that accounting standards are interpreted and applied in domestic markets (Baskerville \& Evans, 2011, p. 1). This essay addresses some of these influences which are cultural influences such as, the religion, the language or translation, and technical skills and 
experience on the process of adoption of International Financial Reporting Standards (IFRS) across the world generally.

\section{Research Limitations}

Because of the increasing popularity of IFRS, this research attempts to identify how the set of cultural influences in some countries and institutions hinder the adoption process of IFRS. Specifically, the study intended to focus only on four cultural factors which are; religion, language, skills and expertise in any given country. Findings of this study can be generalizable to theoretical propositions. However, findings may not significantly be applicable to some countries.

\section{Conclusion}

The main results that are found in this study, there are some IFRS conflict with some of the principles of the Islamic religion; also, there is incorrect implementation of IFRS in some countries because of translation problems of IFRS from English to their local languages, plus, many countries have still problems with implementation of IFRS in terms of lack of the sufficient technical skill and experience of accountants and auditors to deal with these standards. Thus, in the process of globalization, we should not neglect the role of a cultural element. Culture also plays a role in accounting. A better understanding of cultural differences can help to predict the development of accounting in a country, and can help to have a better understanding of the accounting standards, accounting regulations, and the behaviors of the professionals.

\section{References}

Abd-Elsalam, O., \& Weetman, P. (2003). Introducing international accounting standards to an emerging capital market relative familiarity and language effect in Egypt. Journal of International Accounting, Auditing and Taxation, 12(1), 63-84. https://doi.org/10.1016/S1061-9518(03)00002-8

Aldu, C., Albu, N., \& Fekete, S. (2010). The context of the possible for SMES implementation in Romania: An exploratory study. Accounting and Management Information Systems, 9(1), 45-71.

Alkhtani, S. (2012). The relevance of IFRSs to less developed economies: Challenges and opportunities, Saudi Arabia as a case study. Proceedings of Global Accounting. Finance and Economics Conference, Melbourne, $\begin{array}{lllll}\text { Australia, 20-21 } & \text { February } & 2012 . & \text { Retrieved } & \text { from }\end{array}$ http://www.wbiconpro.com/Melbopurne_accounting2012.htm

Anonymous. (2009). BFX appointed as member of AAOIFI. Middle East Company News, 1-2.

Anonymous. (2009). Professors urge IFRS education. Accounting Today, 23(16), 9.

Azmi, S. (2010). An Islamic approach to business ethics. Retrieved from http://alhaqqsociety.wordpress.com

Baskerville, R., \& Evans, L. (2011). The darkening glass: Issues for translation of IFRS. Retrieved from http://ssrn.com/abstract=1910446

Baydoun, N., \& Willett, R. (1995). Cultural relevance of western accounting systems to developing countries. Abacus, 31(1), 67-92. https://doi.org/10.1111/j.1467-6281.1995.tb00355.x

Bodr, M. (2012). Harmonization process of accounting standards and the compliance of the Middle East countries (MEC) with the International Accounting Standards Board (IASB). In M. Greggi (Ed.), Tax law and the Mediterranean area (pp. 23-41). University of Ferrara, Ferrara, Italy.

Chamisa, E. (2000). The relevance and observance of the IASC standards in developing countries and the particular case of Zimbabwe. The International Journal of Accounting, 35(2), 267-286. https://doi.org/10.1016/S0020-7063(00)00049-2

Christopher, N. (2011). IFRS practices and the persistence of accounting system classification. Abacus, 27(3), 267-283.

Clements, C., Neill, J., \& Scott Stovall, O. (2010). Cultural diversity, country size, and the IFRS, adoption decision Clements. Journal of Applied Business Research, 26(2), 115-126. https://doi.org/10.19030/jabr.v26i2.288

Ding, Y., \& Su, X. (2008). Implementation of IFRS in a regulated market. Journal of Accounting and Public Policy, 27(6), 474-479. https://doi.org/10.1016/j.jaccpubpol.2008.09.005

Doupnik, S., \& Richter, M. (2003). Interpretation of uncertainty expressions: A cross-national study. Accounting Organizations and Society, 18(1), 15-35. https://doi.org/10.1016/S0361-3682(02)00010-7

Doupnik, T., \& Richter, M. (2004). The impact of culture on the interpretation of "in context" verbal probability 
expressions. Journal of International Accounting Research, $3(1), \quad 1-20$. https://doi.org/10.2308/jiar.2004.3.1.1

El-Razik. (2009). Challenges of international financial reporting standards (IFRS) in the Islamic accounting world, case of Middle Eastern countries. Scientific Bulletin - Economic Sciences, 18(14), 1-6.

Esposito, J. (2002). Ten Things to Know About Islam. Retrieved from http://www.teachmideast.org/essays/35-religion/58-ten-things-to-know-about-islam

Evans, L. (2004). Language, translation and the problem of international accounting communication. Accounting and Accountability Journal, 29(2), 200-248. https://doi.org/10.1108/09513570410532438

Fang, Y. (2007). On accounting and culture/Computability et culture. Canadian Social Science, 3(5), $121-124$.

Gupta, P., Linthicum, C., \& Noland, T. (2007). The road to IFRS. Institute of Management Accountants, 140(7), 29-33.

Hail, L., Leuz, C., \& Wysocki, P. (2009). Global accounting convergence and the potential adoption of IFRS by the US (Part I): Conceptual underpinnings and economic analysis. Accounting Horizons, 24(3), 353-394.

Harahap, S. (2002). Of Islamic values- annual report the analysis of Bank Muamalat Indonesia's Annual Report. Managerial Finance, 30(10), 35-45.

Hellmann, A., Perera, H., \& Patel, C. (2010). Equivalence of IFRS across languages: Translation issues from English to German. University of Macquarie, Sydney.

Ibrahim, S. (2000). The need for Islamic accounting perceptions of its objectives and characteristics by Malaysian Muslim accountants and accounting academics. PhD thesis, School of Business, Accounting and Finance, University of Dundee, Scotland. Retrieved from http://www.iium.edu.my

Irvine, H., \& Lucas, N. (2006). The globalization of accounting standards: The case of the United Arab Emirates. Proceedings of the 3rd International Conference on Contemporary Business, Leura, New South Wales, 21-22 September 2006. Retrieved from http://works.bepress.com/hirvine/17

La Trobe University. (2012). Currency and banking. Retrieved from http://www.latrobe.edu.au/international/predeparture/leaving/banking

La Trobe University. (2012). Currency and banking. Retrieved from http://www.latrobe.edu.au/international/predeparture/leaving/banking

Lewis, M. (2001). Islam and accounting. Accounting Forum, 25(2), $103-127$. https://doi.org/10.1111/1467-6303.00058

Ludolph, S. (2006). Why IFRS. Accountancy SA, 17-19.

Mullerova, L., \& Pasekova, M. (2010). IFRS for SMSs: Current Issues in the Reporting of SMEs in the Czech Republic. Retrieved from http://iaes.confex.com.

Nandakumar, A., Kalpesh, M., Ghosh, T., \& Yass, A. (2010). Understanding IFRS fundamentals: International Financial Reporting Standards (pp. 1-261). Wiley, Queensland, Australia. Retrieved from http://www.library.uow.edu.au.

Oluku, D., \& Ojeka, S. (2011). The challenge of culture to international financial reporting standards (IFRS) convergence. Interdisciplinary Journal of Contemporary Research in Business, 2(12), 914-924.

Porial, V. (2009). IFRS implementation and challenges in India. Retrieved from www.gigiirs.com

Session two- background paper. (2005). International Reporting Standards regional policy forum. Retrieved from http://www.frc.gov.au/trans_tasman/related_material/downloads/Session2_bp.pdf

Shima, K., \& Yang, D. (2012). Factors affecting the adoption of IFRS. International Journal of Business, 17(3), 276-298.

Stokdyk, J. (2010). EU uncovers resistance to IFRS for SMEs. Retrieved from http://m.accountingweb.co.uk

Taskumis, G., Campbell, D., \& Doupnik, T. (2009). IFRS: beyond the standards (international financial reporting standards). Journal of Accounting, 207(2), 34-39.

The finance group. (2008). IFRS in Canada; dates on changing accounting standards for Canadian public and private companies. Retrieved from http://www.ifrsincanada.com /IFRSinCanadaJan2108.pdf

Tomaszewski, S., \& Showerman, S. (2010). IFRS in the United States: Challenges and Opportunities. Review of 
Business, 30(2), 95-71.

White, L. S. (2004). The influence of religion on the globalization of accounting standards. Retrieved from http://cbfa.org/papers/2004conf/White.doc

Wilson, R. (2004). Regulatory challenges posed by Islamic capital market products and services. University of Durham, UK, IOSCO task force on Islamic.

Zeff, S. (2007). Some obstacles to global financial reporting comparability and convergence at a high level of quality. The British Accounting Review, 39(4), 290-302. https://doi.org/10.1016/j.bar.2007.08.001

\section{Notes}

Note 1. Zakat is one of the most important principles of Islam, and it is an amount of money that every adult, mentally stable, free, and financially able Muslim, male and female, has to pay to support specific categories of people. (http://www.islamicity.com/mosque/zakat/?AspxAutoDetectCookieSupport=1)

Note 2. A not-for-profit organization that was established to maintain and promote Sharia standards for Islamic financial institutions, participants and the overall industry. It was created on $26^{\text {th }}$ of February, 1990. (http://www.aaoifi.com/aaoifi/)

\section{Copyrights}

Copyright for this article is retained by the author(s), with first publication rights granted to the journal.

This is an open-access article distributed under the terms and conditions of the Creative Commons Attribution license (http://creativecommons.org/licenses/by/4.0/). 